\title{
Musical Ties of the Romanian Principalities with Austria Between 1821 and 1859
}

\author{
HAIGANUS PREDA-SCHIMEK
}

During the nineteenth century there was musical migration from cities such as Vienna, Milan, Venice and Prague towards the south and east. That this migration was noticeable in Serbian, Hungarian, Greek and Bulgarian cities was shown at the 17th Congress of the International Musicology Society in Leuven, 2002.[1] A similar phenomenon took place in the Romanian world, which was not documented at this conference. The present article aims at proving that such a transfer also occurred on Romanian territory and that it was not an accidental phenomenon but part of the deeper process of political, social and cultural change suffered by the country after the second decade of the nineteenth century. A number of Austrian musicians arrived in the Romanian principalities precisely at the moment when, through a process largely supported by international politics, the GrecoOttoman way of life was being abandoned in favor of Western habits. Politics, economy, and culture underwent a deep reform that affected mentalities, language and social practices. Foreign musicians of Austrian or Czech origin arrived, invited by princes or by influential local families, or even on their own in search of favorable commissions, and participated in this renewal work, particularly in its first phase (1821-1859).[2]

\section{CULTURAL CONTACTS BETWEEN THE ROMANIAN PRINCIPALITIES AND WESTERN EUROPE BETWEEN 1821 AND 1859}

Musical relations between the Habsburg Empire and the Romanian principalities of Moldavia and Walachia[3] emerged against a different historical background than those in Transylvania, which had belonged since the seventeenth century to the Habsburgs and possessed a longer tradition of Western-orientated music. The phenomenon demands, therefore, a differentiated interpretation according to its historical frame.

In the process of modernizing the Romanian provinces near the Danube, which was quite intense in this period, contacts established 
with Western Europe became stronger and were manifest in many areas of life: in politics, in the decrease of Ottoman court influence and by an increasing interest of the Western powers in the economy, in an increase in imports, improved crafts, and industrialization, in the development of culture through Romanian students studying abroad, in lay education, newspapers and a musical life of European character.[4]

Contacts with fellow Romanesque cultures, such as those of Italy and France, were obviously closer. Language underwent a change, especially with the help of borrowings from French, some coming through Italian. More often than not, Western foreign languages (French, German and Italian) replaced the teaching of Greek and Slavonic.[5] In education, the national language was also introduced.[6] The number of translations from foreign authors increased dramatically, especially from French.[7] Reading halls, partially supervised by librarians of German origin, were also opened.[8]

All this was possible due to the change in international political configurations. Between 1829 and 1834, the Ottoman provinces of Moldova and Walachia were occupied by the Romanov Empire, which started a reform program inspired by the Western tradition, the so-called Organic Regulations.[9] After the departure of tsarist troops, the Westernization process continued due to the effort of intellectuals and young boyars who had been educated in the West.[10] Their actions led to the union of the provinces in 1859, the installation of a foreign monarch from the German Hohenzollern dynasty, and independence from the Ottoman Empire, which was achieved in 1877. Contacts with the West went through a number of phases, from an enthusiastic yet modestly selective absorption of anything "French," "Italian" or "German" to a filtered, critical assimilation adapted to local specificity, manifest as far back as the fourth and fifth decade of the nineteenth century, and still characteristic of highly intellectual Romanian milieus.

\section{TIES WITH AUSTRIA}

International contacts with Romania during this period were mainly economic and cultural in nature. Between 1830 and 1840, most industrial products were exported to the Austrian Empire (A. Popescu 165). Trade on the Danube intensified after 1829 due to trade liberalization.[11] On the cultural level, ties developed in both directions: on the one hand, Romanian intellectuals went to Vienna to study or publish Romanian writings; on the other hand, Viennese and Austrian artists took up temporary or permanent residence in the Romanian 
provinces. They were mainly specialists in architecture and music, fields in which there were not enough local professionals.

A short Habsburg interlude took place in the Romanian provinces in the 1850s. During the Crimean War, Austria fought on Turkey's side and, in full agreement with Turkey, occupied the provinces for a short while (1854-1855). Their interest was purely economic. They intended to improve the means of transport and communication in order to facilitate trading agreements and to set up commercial agencies in major towns. This was also the period that marked the advent of the first Romanian telegraph lines between the two capitals, Iassy and Bucharest. Efforts to influence political life also took plac, with the formation of a pro-Austrian party (M. Popescu 89).

However, cultural ties had already been present for several decades without any direct relationship to political events. As early as the 1830s, Austrian architects were invited to build major projects in Bucharest: the Brancovenian Hospital by Josef Hartl (1835-1857) for instance,[12] and Şuţu Palace, owned by an important family of Walachian boyars (today it houses Bucharest's History Museum) by Johann Veit and Konrad Schwink (1833-1835). In 1843, the Viennese landscape architect Karl Friedrich Wilhelm Meyer was called on to design the parks in the capital city (Ion 116). Building at the site of the imposing National Theater took place between 1846 and 1852, headed by the Austrian Josef Heft. According to one of his compatriots in 1855, it "was comparable to the loveliest theater in Vienna" (M. Popescu 94). The above examples are proof of the "professional migration" of highly qualified specialists to Romania, where there was still no indigenous institutionalized education system. There were, however, a good deal of commissions, enough money and a friendly environment, for which these professionals were ready to leave their country and work for some time, or even settle down.

The same situation applied to Austrian musicians, who were active in Romanian musical life: in army orchestras, in theaters, and in the newly opened music conservatories. Their presence represents one component of a manifold frame of musical contacts with Austria.

\section{MUSICAL TIES WITH AUSTRIA}

Apart from activities led by musicians who had settled in the Romanian provinces, contact points were largely through theater company tours and concert players stopping in southeastern Europe to visit Romanian cities, mostly on their way to Russia. Touring companies, especially French and German ones, generally traveled from the West via Vienna-Budapest-Arad-Timişoara-Sibiu-Braşov up to Bucharest. 
Italian companies often traveled from the East - that is, from KiïvCernăuţi/Chernivtsi towards Iaşi, or from St. Petersburg-Odessa towards Iassy and Bucharest (V. Cosma 26).[13]

Already before 1800 groups of foreign musicians are known to have visited Bucharest. The Swiss historian Joseph Franz Sulzer (Geschichte des transalpinischen Daziens, Vienna, 1781-1782) notes the interest in European music at Prince Alexander Ipsilanti's court.[14] Ipsilanti belonged to an old Greek family from Constantinople which had settled down in the Romanian provinces and married into Romanian aristocrat families in the eighteenth century. He reigned with interruptions in the 1770s and 1780s both in Walachia and Moldavia.[15] There are mentions of the presence of Italian and probably Austrian musicians at the prince's court: Ioan (Giovanni?) Mangli, Franz Truseschi (Truseski?). Also, various Austrian instrumentalists gave concerts in private houses (Werner and Paul Hette, Schulz, Pospischill, Josef Herfner and Franz Caudella are mentioned as having performed in Theodor Burada's house;[16] O. L. Cosma 184). In 1819, an English traveler and diplomat witnessed a performance of Johan Gerger's company playing "German operas and comedies translated into the Walachian language."[17] Starting in the 1830s foreign companies are regularly mentioned as being in Bucharest and Iassy.[18] While in the 1830s German companies were more frequent, the 1840s witnessed an increased presence of French and Italian ones. Local productions rose in number, their authors having either studied in Vienna (Flechtenmacher, for instance) or actually being Austrian (Wachmann, Wiest, etc.). The same tendency is apparent in their repertoire. After 1823 there were a larger number of German lyrical works, whereas in the fourth and fifth decades there were more Italian productions (O. L. Cosma 240). At the same time, the national dramaturgy took shape, with its specific touch inspired by melodies, dances and subjects taken from (mostly urban) folklore. Rossini was the most frequently played composer in the third decade, along with Bellini. It did not take long before works by Verdi and Donizetti took the lead (O. L. Cosma 268-9). That the same composers were the favorites of audiences in Vienna, Paris and other European metropolises indicates the extent to which Romanian public taste was strongly linked to the European pulse of the day.[19] It is surprising how quickly Rossini's works were staged in the principalities, either immediately after their opening night in Italy, or, in most cases, in the same year (O. L. Cosma 269).

During their travels through Eastern Europe, famous artists often gave concerts in the Romanian provinces. The most interesting aspect of their passage through these lands was that, having the occasion to 
listen to Romanian folklore music and wishing to more closely connect with their audiences, they composed small pieces with folkloric themes, among the first of their kind, undoubtedly with great documentary value. Cello player Bernhard Romberg gave a concert in Romania on his way to Russia (1806-1807 and 1812) and composed a Capriccio for cello with Moldavian and Walachian melodies (Breazul 137-138). Franz Liszt gave concerts during a long tour with stops in a large number of towns in Transylvania, in Bucharest and Iassy (December 1846, January 1847). He had the opportunity to listen to Alexander Flechtenmacher's "Moldova" overture conducted by the composer himself and improvised on themes he heard on that occasion; he also listened to fiddle bands in Bucharest, noted down leitmotifs and used them in the Romanian Rhapsody, in Hungarian Rhapsody no. 9 (a Moldavian hora[20]) and in Hungarian Rhapsody no. 2 (a melody heard in Iassy over a glass of wine; cf. Bălan 349-67). In the same year of 1847, Johann Strauß son and his orchestra toured Transylvania on their way to Bucharest. Although programmed, a concert in Iaşi did not take place, possibly because of the 1848 unrest.[21] Inspired by the local music he had listened to, Strauß composed "Klänge aus der Wallachei" Potpourri op. 39.[22] Viennese piano players Sigmund Thalberg (1852), Franz Erkel (1830), Leopold Mayer (1857) and Anton Arnstein (1850), among others, also gave concerts in Iaşi or Bucharest.

I have shown so far that a large number of the foreign visitors present in Romanian musical life of the time were from Austria. Indeed, in those days, Vienna mostly "exported" performers rather than music. The Viennese works of the fourth and fifth decades of the nineteenth century were rarely present in concert programs, neither in Vienna itself nor outside it (Flotzinger 150-1).[23] Rather the genres in great fashion in the Romanian provinces were vaudeville, society dances (polonaise, quadrille, waltz, etc. along with Romanian dances, such as the hora), marches, patriotic anthems, overtures, and also, various arias and aria remakes by Spontini, Monsigny, Mayerbeer, Kreutzer, etc. Small genres were preferred in the absence of professional groups (orchestras, choirs) capable of playing a larger, more complex repertoire.[24] While foreign companies presented their "standard" program in Romania, the same as in Austria, Hungary and Russia, the contemporary repertoire was designed by local theater members according to local tastes. The waltz, popular Viennese melodies such as "O, du lieber Augustin," (Ghica 54-5) and subjects like "Lumpatius vagabundus"[25] by Johann Nestroy once more prove their international character by their presence in Romanian 
milieus as far back as the second and third decade of the nineteenth century.[26]

Vienna was famous for two further musical elements that made Vienna important for the transitional countries: high quality instrument manufacturing and a large number of printing houses specializing in musical scores. Like everywhere else in nineteenth-century Europe, pianos became a common presence in the houses of the Romanian bourgeoisie. Ordered in Vienna, they were brought by carts along the roads that crossed the Carpathians. A branch of Karl Hasse was notably present in Iassy, as were various dealers in Sibiu/Hermannstadt, mediating contacts with Vienna.[27]

Among compositions printed in Vienna in those days, the following should be mentioned: psalms in Romanian by Macarie Ieromonahul (printed by the printing house of the Mekhitarian Armenian monks in 1821[28]); four books of folklore songs remade for piano by J.A. Wachmann (H.F. Müller, H.F. Müllers Witwe, as well as Wessely and Büssing, 1847-1857), "Airs nationaux roumains" by Heinrich Ehrlich (Pietro Mechetti et Carlo, 1850), "Trois airs valaques" by Leopold Mayer (C.A. Spina, around 1848), and "National overture Moldova" by Alexander Flechtenmacher (Wegerlin, 1856).

\section{THE ACTIVITIES OF AUSTRIAN MUSICIANS WITH PERMANENT OR}

\section{TEMPORARY RESIDENCE IN THE ROMANIAN PROVINCES}

Elena Teyber, Franz Rouszitzka (Ruszitski), Johann Andreas Wachmann, Ludwig Wiest, Josef Herfner and Eduard Hübsch were born in the Habsburg Empire, completed their studies in Vienna, came to the Romanian provinces in their youth and stayed there for the rest of their lives.[29] The case of Heinrich Ehrlich was different: born and trained in Vienna, Ehrlich was present in the musical life of the Romanian provinces for only eight years (1842-1850) and later moved on to England, before remaining mostly in Germany (O. L. Cosma 383).[30]

What was the context of these musicians taking up residence in Romanian cities? Hired to put up a small cameral ensemble, Franz Ruszitski came to Bucharest together with his father Wenzel and his two brothers, Karl and Georg, as employees of the Court.[31] When the ensemble broke up in 1813, he went to Iassy as a private music teacher and a piano concert player, and in 1830 he became the head of the military chapel.

Elena (Eleonore) Teyber Asachi, daughter of the Kapellmeister of the Viennese Court Franz Anton Teyber, came to Bucharest as a governess in the house of Mihai Sturdza some time before 1817. Around 
1826 she became the wife of Gheorghe Asachi, one of the major local intellectuals.[32] She is the author of the first original vocalinstrumental Moldavian pieces of Western inspiration, composed for various occasions (meetings and festivities of the Iassy elites).

Josef Herfner came to Iaşi in 1826 as a professor of music and piano. In 1830 he replaced Rouszinski as a conductor of the Iaşi "land guard" (military fanfare), for which he wrote many pieces. He stayed in Iassy for the rest of his life, and his son George became a general in the Romanian army (O. L. Cosma 387).

Starting in 1859, Eduard Hübsch worked as a conductor and composer for the National Theater in Iassy; he also conducted many military orchestras in Bucharest and Craiova between 1861 and 1894, and served as concert-maestro of the Romanian Philharmonic Orchestra (1868-1894) and as conductor of the National Theater in Bucharest (1880-1893).

Johann Andreas Wachmann, the most influential and productive of the Austrian musicians in Romania, came to Bucharest as the conductor of the Theodor Müller theater company of Timişoara (whose leader he was until 1835). He worked as a conductor in a musical theater and as a teacher.[33] He taught in the first school of vocal and instrumental music in Bucharest (1835-1837), and later at the famous St. Sava College (1846-1850).[34] He composed music in all the genres then in fashion.

Ludwig Wiest was invited, as Rouszitski had been two decades earlier, by the Walachian prince, in order to reorganize and lead the court orchestra (1838-1845). When his engagement ended, he served, among other positions, as first violinist of the Italian Opera (18441860) and of the Romanian Philharmonic Society (1868-1877), as conductor at the National Theater (1860-1880) and as a violin teacher at the Music Conservatory in Bucharest (1864-1889).

These musicians were obviously very active in the musical life of the Romanian provinces. How can this be explained? In the 1830s and 1840s, there were few qualified and experienced musicians, and education institutions were just emerging. In this precarious situation, typical of any beginning, calls for help from existing musicians came "from everywhere": in ensemble work, in teaching, as solo performers and Kapellmeisters; as composers, they were expected to write music for the most diverse occasions. Although their description by historians as "pioneers" might be termed somewhat superficial in many instances, they must have had, if not a thorough musical background,[35] at least enough resources to answer the manifold requirements of artistic life at that time. Through their responsibilities they gained experience and gradually acquired complex skills. Johann 
Andreas Wachmann's profile is close to that of a complete musician: a professor, conductor, performer, composer and folklore collector. Wiest was also an outstanding performer. The chronicles of the time, as well as his violin compositions, recommend him as an exceptional, highly skilled violin player - a virtuoso. Herfner distinguished himself as an excellent composer of military music.

Apart from their frequent participation in musical life, Austrian composers integrated well into Romanian society. Here is a chronicle from 1888:

These composers were foreign only in their origin, since, in feeling, they were more Romanian than many Romanians today; they deeply loved the country they lived in and cherished its melodic richness, so closely linked to the people; all their compositions lay proof of their national spirit. (Roşca 188)

This feeling was probably mutual. The foreign musicians collected folklore, rearranged and published it, wrote anthems, marches, Union horas, and operas with national subjects. Possibly, there was also a personal motivation for writing those pieces, in connection with the Romantic ideals of the day. Their attachment to the "national cause" is obvious in the prefaces to folklore collections, in memoirs of Romanian contemporaries (Vasile Alecsandri's appreciation for Heinrich Ehrlich), and in their delicate approach to folklore sources. We can imagine them acting in kinship with the Romanian intellectuals. Ehrlich participated in the 1848 unrest, wrote music for the "subversive" lyrics of Cezar Bolliac, and was sentenced and imprisoned for a short while. In prefaces to folklore collections (which were published in Vienna), Wachmann and Ehrlich declared their progressive convictions, their affinity with the melodic Romanian folkloric touch and for the ideology of the union of Walachia with Moldavia (achieved on January 24,1859$)$.

Romanian musicology defines them as "Romanian pre-unionist composers." [36] It acknowledges their importance as "founders" and nuances the value of their compositions in comparison to later developments. Their music "should not be judged with the exigencies of a different sensibility than that of the age which generated them, and which they addressed" (O. L. Cosma 284).

These "pioneers" are often treated condescendingly and looked down upon; yet they set the basis for the musical life that was to come. What in the 1830s seemed precarious and lacking any chance of survival later proved to be solid and viable. This would never have been possible without their professionalism and perseverance. 
The Austrian musicians who lived in the Romanian provinces did not act as a national or professional group. They acted individually, came with temporary engagements, but stayed for a long time and, ultimately, played a crucial part in the reform program. Eduard Wachmann, Johann Andreas' son, became the founder, conductor and director of the Philharmonic orchestra of Bucharest (1868-1906), a professor and director of the Music Conservatory in Bucharest (18641903), and director of the Romanian Opera House (1895-1901). Julius (Iuliu) Wiest, Ludwig's son, is mainly known as a composer. They represented a new generation, able to build on the foundation of their predecessors' work. Like Gh. Dima, Constantin Dimitrescu, Tudor Flondor, Iacob Mureşianu, Ciprian Porumbescu, they started their musical education in Romania and later went to Vienna to complete it (Petecel 131).

The ties with Vienna flowed in the opposite direction after 1860. It was not the Austrian composers who came to Romania in search of work but talented Romanian musicians who went to Vienna to perfect their skills, and some even managed to make brilliant careers for themselves, for instance, Eusebius Mandicevski from Bucovina[37] and George Enescu, who studied between 1888 and 1894 at the Viennese Conservatory.

\section{NOTES}

[1] See Kipriana Belivanova, "Musical-Cultural Gravitations in the Development of Musical Cultures during the 19tTH and 20th Centuries (According to Materials of the Musical History of Bulgaria and the Balkan Countries)", Ekaterini Romanou, "Italian Musicians in Greece During the 19th Century", Christina Vergadou-Mavroudaki, "Greek Composers of the Romanian Islands in Italian Musical Life During the 19th Century" and Katarina Tomašević, "The Contribution of Czech Musicians to Serbian Music in the 19th Century", Programm and Abstracts of the 17th Congress of the International Music Society. Leuven: Alamire Foundation, 2003. 170, 173, 212, 228.

[2] The work of the Austrian musicians that we are dealing with may be included, for illustrative purposes, in the timeframe between Tudor Vladimirescu's Revolution of 1821 and the union of the provinces in 1859. This is the first, "pioneering" phase, a time of growth and transition between the Eastern towards the Western system. Part of these composers indeed continued their activity and, after 1859, their works went through a new mature phase. Apart from that, a new generation of local musicians was born, bringing a lively, fresh spirit into Romanian composition.

[3] The name "Walachia" (Romanian: "Țara Românească" or "The Romanian Land", also "Muntenia") designates the region which is now Southern Romania; "generally not used by Romanians themselves (but present in some 
contexts as Valahia or Vlahia), is derived from the Valachs - a word of German origin also present as the Slavic Vlachs - used by foreigners in reference to Romanians" http: / / en.wikipedia.org/wiki/Walachia.

[4] Sources of the time mention a boom in consumption and an increase in imports from Nürnberg, Leipzig, Austria and France. Eastern attire was gradually replaced by Western clothing; new crafts and craftspeople appeared, such as women's tailors and cap-makers. Craftspeople were organized in larger, more modern groups (guilds). For details about the Bucharest economy and daily life, see Berindei, ch. 6 and Hitchins 182.

[5] Romanian was introduced in Bucharest schools opened by churches and monasteries only in the eighteenth century. Priests were taught Greek. See Berindei, and Urechia 268.

[6] The founders of the first secondary schools in Bucharest and Iaşi with teaching in Romanian - Gheorghe Lazăr and Gheorghe Asachi - had studied in Vienna, Lazăr - Theology and Engineering, Asachi - Engineering and Archaeology (A. Popescu 219 and Lovinescu 23)

[7] The German authors mentioned in the reading halls in Iaşi and Bucharest were Schiller, Goethe, Gessner and Herder (Cornea 447).

[8] The Court librarians in Bucharest were, in the 1830s, Friedrich Walbaum and (?) Weiss; supervision of the reading halls was ensured by C.A. Rosetti and Heinrich (Enric) Winterhalter (Cornea 455-7).

[9] Following the Adrianopolis peace (1829), Russia was recognized by the Ottoman Court as the protecting power of the Romanian provinces. In this position it asked the princes and boyars to come up with a set of rules of European inspiration meant to reorganise public and economic life; this set of rules is known as the Organic Regulations. Among other things, it referred to the separation of powers in the state (for the first time in the provinces), a modernized monetary system, the approval of an annual budget based on planned income and costs, diminished Church powers in civil problems, and reforms in the field of culture.

[10] The term "boyar" (from the Romanian "boier," derivate of the Slavonic "boljarinŭ") designates a nobleman, landowner and high official in the feudal state.

[11] With the peace treaty of Adrianopolis, following the war of 1828-1829 between the Russians and the Turks, the Sultan recognized the political and administrative autonomy of the Romanian provinces and agreed to complete freedom of trade with all countries. Proof of free trade on the Danube is the foundation of a Maritime Transport Society in Vienna in 1829, by a group of tradesmen from Bucharest (A. Popescu 165).

[12] The Brancovenian Hospital, the most modern and best equipped hospital in Bucharest in the first half of the nineteenth century, was commissioned by Safta Brancoveanu, planned by Josef Hartl and inaugurated in 1838 by Prince Alexandru Ghica (1834-1842); it was demolished during the "reorganization campaign" of the city capital in the last stage of Ceauşescu's regime in 1984.

[13] Viorel Cosma, "Inceputurile teatrului românesc", Muzica 3 (1967): 26. 
[14] Sulzer says that Prince Alexander Ipsilanti asked the Mayor (Magister) of Braşov to hire musicians for his Court in Bucharest, as well as for the education of his children in "European music" (O.L. Cosma, vol. 1, 359).

[15] Alexandru Vodă Ipsilanti was prince of Walachia between September 1774 and February 1782 as well as between August 1796 and December 1797; in Moldavia he reigned between December 1786 and April 1788.

[16] A writer, lawyer, ethnomusicologist, and professor at the Conservatory, Theodor Burada (1839-1923) was a central personality in Iaşi's cultural life. His musicological writings are: "A History of the Theater in Moldova" (with information about musical life and music theater), "Bocetele populare la români", 1878-1884; "O călătorie In Dobrogea" (the first monographic research about Romanian folkore), 1880; "Cântecul cununii", 1880-1881; “Datinile poporului roman la înmormântări" (1882), "Poezii populare adunate din Macedonia," etc.

[17] V. Cosma, Două milenii de muzică pe pământ românesc 48.

[18] In Bucharest, the following companies were present: the Eduard Kreibig Company in 1830; the French company the Foureaux brothers in 1831; the Theodor Muller company between 1833 and 1835; and the German company Zimmermann between 1835 and 1836. During the 1838 season the German company of Ignatz Firsch presented no less than 36 pieces. Between 1839 and 1840 Theodore Geoffrey's French company played here; in 1843 the Italian Theater was inaugurated under the direction of Basilio Sansoni; in 1850-1851 the Romanian company of the National Theater gained recognition under the direction of Costache Caragiale (the conductor was I.A. Wachmann, whose compositions were present in large number during the 1852-1853 season), followed in 1852 by the inauguration of the National Theater with the overture "Steaua păstorului" ("A Peasant Gathering") by Wachmann. The Variety Theater in Iaşi opened in 1832, with the brothers Joseph and Baptiste Foureux' company; the French companies Hette and Victor Filhol played between 1839 and 1840 (later to merge, under government decree, with a Romanian company, under the directorship of Costache Negruzzi, Vasile Alecsandri and Mihail Kogălniceanu). In Iaşi, in 1844, the shows of M.T. Frisch company are mentioned, along with a tour made by Josef Marini's Italian company (coming from Odessa) and, between 1850 and 1851, the Italian opera of Pietro Tozzoli. (O. L. Cosma, vol. 2, 212-77).

[19] The Viennese musical theater before 1848 was dominated by Italian, French and German imports. After 1848, in spite of the tendency that politics tried to impose (in the age of absolutism) - that of marginalizing Italian opera, it remained the audiences' favourite until 1870, especially Rossini, Bellini, Donizetti and Verdi (Flotzinger 150-1).

[20] An old Romanian round or row dance, done throughout the Romanian territory, mostly in slow motion, both in instrumental and vocal settings. The term derives from the Greek $\chi 0 \varrho \varepsilon i ́$, in old Greek tragedy, a sung round dance (Firca 231-2).

[21] An incident at the Austrian Consulate in Bucharest is well known. The Austrian colony had organixed, during Strauß' stay in town, a protest against 
Chancellor Metternich; the composer also took part. In the purest spirit of Straußian light opera, it is said that the musician fought "in a shining Kapellmeister uniform" with his sword against the Consulate guards, unwillingly cutting the golden straps on the Consul's uniform and losing his "decked-out cap," later to be sent to Vienna as proof. Whether the event indeed happened, it remains one of many "historical" mysteries. See "Johann Strauß-son, a presence in the context of Romanian musical life in the last century" (The Almanac of the Romanian-Orthodox parish in Vienna XV/1976, 148).

[22] Ibid 149.

[23] There was a comeback of Haydn, Beethoven and Schubert, while the local production was stagnating (Flotzinger 150-1).

[24] The foundation of a symphonic orchestra was laid only in 1866, and a permanent orchestra only began in Bucharest in 1868 .

[25] The subject of Nestroy's play was developed by J. A. Wachmann and presented at the National Theater of Bucharest in the 1852-1853 season.

[26] To some extent, the popularity of such motifs led to the clichés that "willingly or unwillingly" mark musical Vienna until today.

[27] As shown in the letter exchange between Iaşi, Sibiu and Vienna, among representatives of the Romanian boyars (O. L. Cosma, vol. 2, 115).

[28] The Theoriticon published in Vienna in 1823 was republished by the publishing house of the Romanian Academy, Bucharest, 1976, including a large number of critical views by Titus Moisescu.

[29] Chronologically, Franz Ruszitski is acknowledged to have been there before 1813, Elena Teyber before 1817, Herfner since 1826, Wachmann since 1831, Wiest since 1838, Hübsch since 1859 (O. L. Cosma, vol. 2, 383-393 and V. Cosma, Lexiconul muzicienilor români. 240, 388, 462, 465).

[30] Between 1855 and 1862 he was in Wiesbaden, London, Frankfurt am Main and Hanover, as a guest of King George V. He then taught piano at the Berlin Conservatory for ten years (O. L. Cosma, vol. 2, 383).

[31] Note that before 1813 (the year when the Chapel was closed by Prince Caragea) the Court in Bucharest showed great interest in Western music.

[32] Gheorghe Asachi (1788-1869), a major Romanian cultural personality in the first half of the nineteenth century, studied in Lemberg, Vienna (Engineering, Astronomy) and Rome (Archaeology, Epigraphy, Poetics, Painting and Sculpture in Keck and Canova's studios). He also practiced all art forms, but his name is remembered only in the history of literature, press and theater. He was spiritus rector of Moldavian cultural life until he retired in 1848.

[33] Wachmann was a conductor for the Costache Caragiale company in Bucharest between 1850 and 1852, for the orchestra of the National Theater in the same city between 1852 and 1858, and for the National Theater in Craiova between 1858 and 1860 (V. Cosma, Lexiconul muzicienilor români 462).

[34] Founded in 1835 within the Philharmonic Society in Bucharest.

[35] Some of them had studied at home, in the tradition of father-to-son skills, as had Franz Rouszitzki. As for others, even Wachmann, it is known that they had started their studies, but never finished them, at the Vienna Conservatory. 
[36] O. L. Cosma, vol. 2, ch. "Musical Creation between 1800 and 1850."

[37] Born in Cernăuţi in 1857, Eusebiu Mandicevschi studied in Vienna with Eduard Hanslick and Gustav Nottelbohm, and stood out as a teacher, musicologist, choir conductor and composer in the musical milieu of Vienna around 1900. A close friend of Johannes Brahms, he became the executor of the latter's will with reference to his musical inheritance. He was a director of the Archive and Library of the Gesellschaft der Musikfreunde in Wien (18871927), a professor at the Viennese Conservatory (1896-1909), and a musical correspondent for the London Musical Times (1901-1908).

\section{REFERENCES}

Berindei, Dan. "Bucharest between 1822 and 1848." Istoria oraşului Bucureşti. Vol. 1, Bucharest: City Museum, 1965.

Bălan, Theodor. Franz Liszt. Bucharest: Editura muzicală, 1963.

Breazul George. "Contribuţii la cunoaşterea trecutului nostru musical." Pagini din istoria muzicii româneşti, vol. 2. Bucharest: Ed. muzicală, 1974.

Cosma, Octavian Lazăr. Hronicul muzicii româneşti, vols. 2 and 3. Bucharest: Editura Uniunii compozitorilor şi muzicologilor din România, 1974.

Cosma, Viorel. "Inceputurile teatrului românesc.” Muzica 3 (1967).

---. Două milenii de muzică pe pământ romanesc. Bucharest: Ed. Ion Creangă, 1977.

---. Lexiconul muzicienilor români. Bucharest : Ed. muzicală, 1970.

Cornea, Paul. Originile romantismului românesc. Bucharest: Ed. Minerva, 1971.

Firca, Gheorghe. "Hora." Diç̧ionar de termeni muzicali. Bucharest: Editura ştiinţifică şi encicolopedică, 1984.

Flotzinger, Rudolf. Geschichte der Musik in Österreich. Vienna, Graz, Cologne: Verlag Styria, 1989.

“Johann Strauß-fiul, o prezenţă în contextul muzicii româneşti în Viena veacului trecut".

Ghica, Ion. Scrisori către Vasile Alecsandri. Bucharest: Editura pentru literatură, 1967.

Hitchins, Keith. Istoria României. Bucharest: Ed. Enciclopedica, 1998.

Ion, Narcis Dan. Bucureşti. In căutarea micului Paris. Bucharest: Tritonic, 2003.

Lovinescu, Eugen. Gheorghe Asachi. Viaţa şi opera. Bucharest: Ed. Casa Şcoalelor, 1927.

Petecel, Despina. "Muzicieni români în Viena secolului al XIX-lea." Almanahul parohiei române din Viena (1976): 129-41.

Popescu, Alexandru. Viena românească. Bucharest: Editura Fundaţiei culturale române, 2000.

---. Die Beziehungen Rumäniens und Österreichs. Bucharest: Institutul european, 1999.

Popescu, Mihai. "Descrierea oraşului Bucureşti făcută de căpitanul austriac Stefan Dietrich în 1855." Vechiul Bucureşti. I-IV (1930-1934), 1935.

Roşca, Iuliu. De prin Bucureşci. Muzica la sfârşit şi început de secol, 1882-1904. Ed. Petecel Despina. Bucharest: Ed. muzicală, 1987.

Programm and Abstracts of the 17th Congress of the International Music Society. Leuven: Alamire Foundation, 2003. 
Urechia, Vasile Alexandrescu. Istoria şcoalelor, vol.1, 1892. 